\title{
Asymmetric heterometal string complexes: stereochemical control of the unique isomer of $(4,0)\left[\mathrm{CuCuPd}(\mathrm{npa})_{4} \mathrm{Cl}_{[}\left[\mathrm{PF}_{6}\right]\right.$ and $(4,0)\left[\mathrm{CuCuPt}(\mathrm{npa})_{4} \mathrm{Cl}\right]\left[\mathrm{PF}_{6} \mid \dagger\right.$
}

\author{
Isiah Po-Chun Liu, ${ }^{a b c}$ Chi-Hui Chen, ${ }^{a}$ Chi-Fen Chen, ${ }^{a}$ Gene-Hsiang Lee ${ }^{a}$ \\ and Shie-Ming Peng*ab
}

Received (in Cambridge, UK) 29th September 2008, Accepted 7th November 2008

First published as an Advance Article on the web 4th December 2008

DOI: $10.1039 / b 817032 k$

This paper describes the synthesis and physical properties of a unique metal string complex isomer containing an asymmetric heterometallic backbone.

Metal string complexes are of considerable significance because of their potential applications as molecular electronic devices. ${ }^{1}$ The typical conformation of this family consists of a onedimensional polymetallic backbone surrounded by organic ligands. Electrons are expected to travel from one electrode to another through this wire-like framework. Because of this potentially useful property, a series of metal string complexes have been synthesized and studied by our group and others. ${ }^{2}$ Their conductivity has also been investigated and reported. ${ }^{3}$ During the last few years, our interest has moved particularly toward the heterometal string complexes. ${ }^{4}$ The insertion of one or several heteronuclear(s) in a homometallic string represents a new avenue by which novel metal string complexes may be developed. In our previous reports, we synthesized heterometal string complexes by employing the symmetric dipyridylamide $\left(\mathrm{dpa}^{-}\right)$ligand. In these complexes, the $\mathrm{M}$ atoms $(\mathrm{M}=\mathrm{Pd}$ and $\mathrm{Pt}$ ) have a tendency to coordinate to the amido $\mathrm{N}$, which may be attributed to the different ligand field strengths of an amido $\mathrm{N}$ and a pyridino $\mathrm{N}^{4 a, b}$ This suggests that an asymmetric heterometallic framework could be designed by carefully arranging the amido $\mathrm{N}$ and the pyridino $\mathrm{N}$ of the ligand. Here we report the synthesis, $\mathrm{X}$-ray structure, magnetic properties and DFT calculations of $(4,0)\left[\mathrm{CuCuPd}(\mathrm{npa})_{4} \mathrm{Cl}\right]\left[\mathrm{PF}_{6}\right]$ (1 $\ddagger$ ) and $(4,0)\left[\mathrm{CuCuPt}(\mathrm{npa})_{4} \mathrm{Cl}\right]\left[\mathrm{PF}_{6}\right](\mathbf{2} \S)$ which supported by the anion of new asymmetric 2-naphthyridylphenylamine (Hnpa) anion.

The Hnpa ligand (Scheme 1) was prepared by reaction of 2-chloro-1,8-naphthyridine $\mathrm{e}^{3 d, 5}$ and aniline with a palladium catalyst. Treatment of $\mathrm{Hnpa}$ with $\mathrm{CuCl}_{2}$ and $\mathrm{K}_{2} \mathrm{PdCl}_{4}$ (or $\left.\mathrm{K}_{2} \mathrm{PtCl}_{4}\right)$ in the presence of $\mathrm{t}-\mathrm{BuOK}$, followed by excess of $\mathrm{KPF}_{6}$, generated compound $\mathbf{1}$ or $\mathbf{2}$. The crystal structures of $\mathbf{1}$ and $\mathbf{2}$ are similar (Fig. 1 and Fig. S1). $\|$ The core structures of $\mathbf{1}$ and 2 reveal a $\left(\mathrm{Cu}_{2} \mathrm{M}\right)^{6+}(\mathrm{M}=\mathrm{Pd}$ for 1 and $\mathrm{Pt}$ for $\mathbf{2})$ chain

${ }^{a}$ Department of Chemistry, National Taiwan University, Taipei,

106 Taiwan, (ROC).E-mail: smpeng@ntu.edu.tw;

Fax: (+ 886) 2-8369-3765

${ }^{b}$ Institute of Chemistry, Academia Sinica, Taipei, 115 Taiwan, ( $R O C$ )

${ }^{c}$ Current address: Department of Chemistry, Purdue University, West Lafayette, IN 47907, USA

$\dagger$ Electronic supplementary information (ESI) available: Fig. S1, Fig. S2, Fig. S3, computational details, X-ray structure determinations. CCDC 703959-703960. For ESI and crystallographic data in CIF or other electronic format see DOI: $10.1039 / \mathrm{b} 817032 \mathrm{k}$ helically wrapped by four $\mathrm{npa}^{-}$ligands. The $\mathrm{npa}^{-}$ligands adopt a $(4,0)$ arrangement with all anilino $\mathrm{N}$ ions coordinated to the $\mathrm{M}$ atom, and all naphthyridine $\mathrm{N}$ atoms coordinated to two $\mathrm{Cu}$ atoms, which exhibits approximated $C_{4}$ symmetry. Due to the steric effect of the four phenyl groups, the counteranion could not approach the $\mathrm{M}$ atom in the axial position, which causes the $\mathrm{M}$ atom to be square planar coordinated. The coordination environment of the terminal copper of $\mathbf{1}$ and 2 forms a distorted square pyramid; the coordination environment of the inner copper is distorted square planar. The interesting feature here is the unique $(4,0)$ conformation of 1 and $\mathbf{2}$, because this conformation may be controlled by utilizing hetero-metal atoms. The $\mathrm{M}$ atom prefers to bond to four anilino $\mathrm{N}$ ions, which avoids the presence of other regioisomers which result from the inequivalence of the asymmetric ligand. ${ }^{6}$ When asymmetric heterometal string complexes are synthesized using the symmetric dpa ligand, a significantly disordered structure results which causes poor X-ray characterization accuracy. ${ }^{4 a-d}$ Compounds $\mathbf{1}$ and $\mathbf{2}$ do not possess this problem. The two terminal $\mathrm{Cu}$ and $\mathrm{M}$ atoms of $\mathbf{1}$ and $\mathbf{2}$ can be clearly identified by X-ray crystallography, because of the high asymmetry of the molecules.

The temperature-dependent magnetic susceptibility of $\mathbf{1}$ and $\mathbf{2}$ was investigated (Fig. 2 and Fig. S2 $\dagger$ ). Their magnetic behaviours are similar. The $\chi_{\mathrm{M}} T$ value at $300 \mathrm{~K}\left(\right.$ ca. $\left.0.5 \mathrm{~cm}^{3} \mathrm{~K} \mathrm{~mol}^{-1}\right)$ is significantly lower than the expected value for two independent $\mathrm{Cu}$ (II) metal centers $\left(0.75 \mathrm{~cm}^{3} \mathrm{~K} \mathrm{~mol}^{-1}\right)$, which is due to the strong antiferromagnetic interaction. The appearance of the $\chi_{\mathrm{M}} T$ value at $4 \mathrm{~K}$ should be assigned to the presence of a paramagnetic impurity. The magnetic susceptibility data were fitted by a simple isotropic dinuclear Heisenberg model $\left(H=-J \mathrm{~S}_{1} \mathrm{~S}_{2}\right)$ with the consideration of the temperature-independent paramagnetism (TIP). ${ }^{7}$ The best fit parameters are $J=-498.90 \mathrm{~cm}^{-1}$, $g=2.00, \chi_{\text {TIP }}=0.00078 \mathrm{~cm}^{3} \mathrm{~mol}^{-1}$ and $R^{2}=0.9998$ for 1, and $J=-501.24 \mathrm{~cm}^{-1}, g=1.92, \chi_{\text {TIP }}=0.00089$ and $R^{2}=0.9991$ for 2 . Both results show a strong antiferromagnetic interaction between two $\mathrm{Cu}$ atoms. This antiferromagnetic<smiles>c1ccc(Nc2ccc3cccnc3n2)cc1</smiles>

Scheme 1 


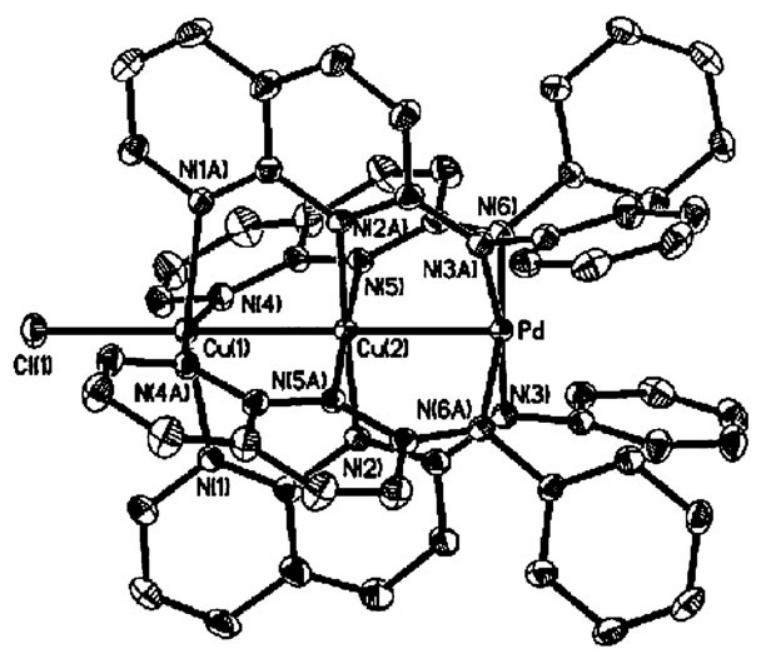

Fig. 1 ORTEP view of the molecular structure of the cation $\left[\mathrm{CuCuPd}(\mathrm{npa})_{4} \mathrm{Cl}\right]^{+}$in $\mathbf{1}(30 \%$ probability). Hydrogen atoms have been omitted for clarity. Selected bond distances (averaged): $\mathrm{Cu}(1)-\mathrm{Cl}$ 2.388(7), $\quad \mathrm{Cu}(1)-\mathrm{Cu}(2) \quad 2.489(4), \quad \mathrm{Cu}(2)-\mathrm{Pd} \quad 2.426(3), \quad \mathrm{Cu}(1)-\mathrm{N}$ 2.084(16), Cu(2)-N 1.994(15), Pd-N 2.028(16) ̊.

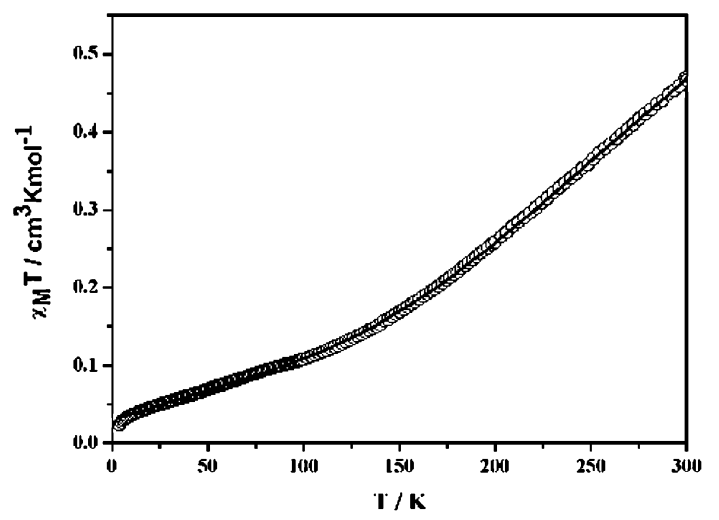

Fig. 2 Plot of $\chi_{\mathrm{M}} T$ versus $T$ for $\mathbf{1}$. The solid line represents the best theoretical fit.

interaction results from the through-space delocalization of the spin density between the $d_{x 2-y 2}-\mathrm{N}$ orbitals of adjacent $\mathrm{Cu}$ atoms. $^{4 b, 8}$

The DFT/B3LYP calculations were carried out on $\mathbf{1}$ and $\mathbf{2}$ with the Gaussian 03 software package. ${ }^{9}$ For the sake of simplicity, the phenyl ring of the ligand $\mathrm{npa}^{-}$is replaced by a methyl group. The crystal structures of $\mathbf{1}$ and $\mathbf{2}$ are well reproduced by the calculations (Fig. 3 and Fig. S3†). In agreement with experimental results, our calculations for $\mathbf{1}$ and $\mathbf{2}$ give significant antiferromagnetic interactions $\left(J_{\text {calcd }}=\right.$ $-572.51 \mathrm{~cm}^{-1}$ for 1 and $-556.75 \mathrm{~cm}^{-1}$ for 2 ). The spin population for the triplet state of $\mathbf{1}$ and $\mathbf{2}$ (see Fig. 3 and Fig. S3) support the coupling mechanism. The spin density of the bridging carbon atoms is $\sim 0.00$, which indicates the spin delocalization is through space between neighboring nitrogen atoms instead of through the other atoms of the rings.

We consider that $\mathbf{1}$ and $\mathbf{2}$ have potential applications as molecular rectifiers. In 1974, Aviram and Ratner proposed a prototype molecular rectifier based on a donor-bridge-acceptor $(\mathrm{D}-\sigma-\mathrm{A})$ molecule. Because of its electronic asymmetry, a rectifier preferably passes the current in one direction. ${ }^{10}$

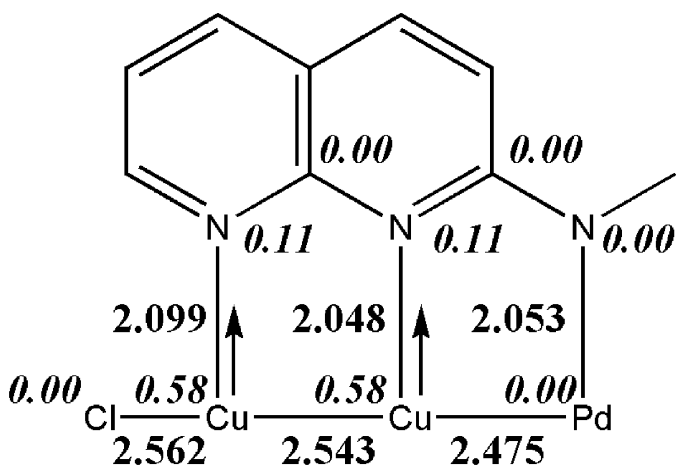

Fig. 3 Selected computed bond distances $(\AA)$ and atomic spin densities (italics) for $\mathbf{1}$.

However, most of the molecular rectifiers are designed with organic molecules and an inorganic compound-containing rectifier is very rare. ${ }^{11}$ The concept to design compound $\mathbf{1}$ and $\mathbf{2}$ seems a reasonable strategy for the development of inorganic molecular rectifier. Although $\mathbf{1}$ and $\mathbf{2}$ do not possess the typical $\mathrm{D}-\sigma-\mathrm{A}$ framework, the large energy barrier between the $3 \mathrm{~d}$ and $4 \mathrm{~d}(5 \mathrm{~d})$ orbitals of adjacent $\mathrm{Cu}$ and $\mathrm{Pd}(\mathrm{Pt})$ atoms may prefer to allow the current to flow in one direction (Fig. 4). That is, the electronic asymmetry of the asymmetric heterometal string complex may cause a voltage drop across the molecule and a corresponding asymmetric $I-V$ response.

In summary, through the reaction of the asymmetric Hnpa ligand, we have prepared two asymmetric heterometal string complexes. The molecular structures of $\mathbf{1}$ and $\mathbf{2}$ were well determined in terms of X-ray crystallographic analysis. Due to the difference in coordination ability between nitrogen and metal atoms, compound $\mathbf{1}$ and $\mathbf{2}$ form a unique $(4,0)$ geometry. The magnetic measurements suggest that the unpaired

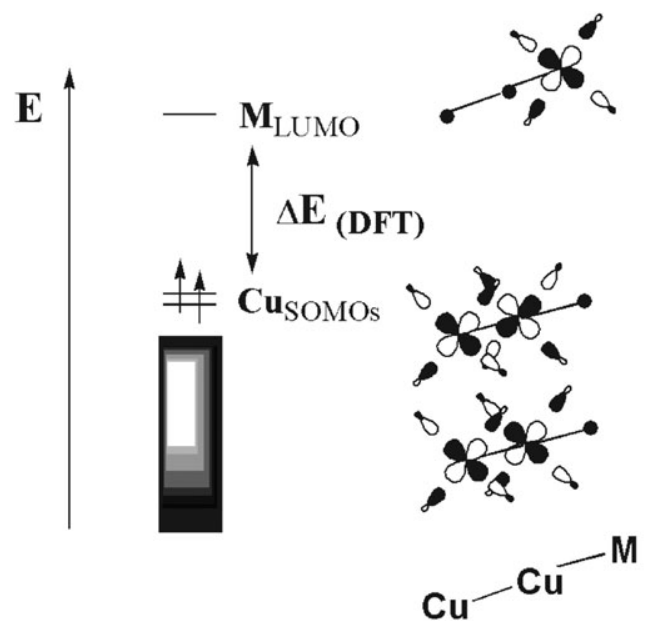

$$
\Delta \mathrm{E}_{(\mathrm{DFT})}=5.29 \mathrm{eV}(\mathrm{Pd}), 6.00 \mathrm{eV} \text { (Pt) }
$$

Fig. 4 Qualitative sequence of the metal orbitals obtained from DFT calculation. The $\Delta E$ represents the energy gap between the singly occupied MOs (SOMOs) and lowest unoccupied MO (LUMO). The SOMOs are mainly composed of two $\mathrm{Cu}$ atoms while the LUMO is mainly localized on the $\mathrm{M}$ atom. The rectangles represent the occupied MOs. 
electrons of the $\mathrm{Cu}$ atoms are antiferromagnetically coupled, which was confirmed by DFT calculations. Because of the energy barrier between the d-orbitals of neighboring heteroatoms, these molecules may exhibit rectifier-like behaviour and are suitable candidates for future inorganic molecular rectifiers. Further experiments are currently in progress to extend the potential of this research.

The authors thank the National Science Council of Republic of China for financial support.

\section{Notes and references}

$\ddagger$ Synthesis of $(4,0)\left[\mathrm{CuCuPd}(n \mathrm{na})_{4} \mathrm{Cl}\right]\left[\mathrm{PF} \mathrm{F}_{6}\right]$ (1). Hnpa (0.89 g, $4 \mathrm{mmol}), \mathrm{CuCl}_{2}(0.27 \mathrm{~g}, 2 \mathrm{mmol}), \mathrm{K}_{2} \mathrm{PdCl}_{4}(0.33 \mathrm{~g}, 1 \mathrm{mmol})$ and $40 \mathrm{~g}$ naphthalene (as solvent) were placed in an Erlenmeyer flask. After stirring the mixture at $150{ }^{\circ} \mathrm{C}$ for $2 \mathrm{~h}, \mathrm{t}-\mathrm{BuOK}(0.44 \mathrm{~g}, 4 \mathrm{mmol})$ in t-BuOH $(30 \mathrm{~mL})$ was added dropwise. The resulting solution was then stirred for an additional $3 \mathrm{~h}$. After cooling the mixture to $80{ }^{\circ} \mathrm{C}$, hexane was added and the resulting precipitate was filtered out. The metal complex was extracted with $\mathrm{CH}_{2} \mathrm{Cl}_{2}$ and treated with $\mathrm{KPF}_{6}$ $(0.36 \mathrm{~g}, 2 \mathrm{mmol})$ in $\mathrm{CH}_{2} \mathrm{Cl}_{2}(100 \mathrm{ml})$. The resulting solution was stirred for a week and dried under vacuum. The compound 1 was extracted with $\mathrm{CH}_{2} \mathrm{Cl}_{2}$ and recrystallized in DMF-ether (yield: $25 \%$ ). MS(FAB) $m / z: 1147\left[\mathrm{CuCuPd}(\mathrm{npa})_{4} \mathrm{Cl}\right]^{+}, 1112\left[\mathrm{CuCuPd}(\mathrm{npa})_{4}\right]^{+}$; EA (\%): $\left[\mathrm{CuCuPd}(\mathrm{npa})_{4} \mathrm{Cl}\right]\left[\mathrm{PF}_{6}\right] \cdot\left[\mathrm{HCON}\left(\mathrm{CH}_{3}\right)_{2}\right]$ : calcd. C 51.80, $\mathrm{H} 3.46, \mathrm{~N}$ 13.31; found: C 52.32, H 3.96, N, $13.46 \%$.

$\S$ Synthesis of $(4,0)\left[\mathrm{CuCuPt}(n \mathrm{na}){ }_{4} \mathrm{Cl}\right]\left[\mathrm{PF}_{6}\right]$ (2). Hnpa $(0.89 \mathrm{~g}$, $4 \mathrm{mmol}), \mathrm{CuCl}_{2}(0.27 \mathrm{~g}, 2 \mathrm{mmol}), \mathrm{K}_{2} \mathrm{PtCl}_{4}(0.42 \mathrm{~g}, 1 \mathrm{mmol})$ and $40 \mathrm{~g}$ naphthalene (as solvent) were placed in an Erlenmeyer flask. After stirring the mixture at $150{ }^{\circ} \mathrm{C}$ for $3 \mathrm{~h}, \mathrm{t}-\mathrm{BuOK}(0.44 \mathrm{~g}, 4 \mathrm{mmol})$ in $\mathrm{t}-\mathrm{BuOH}(30 \mathrm{~mL})$ was added dropwise. The resulting solution was then stirred for an additional $4 \mathrm{~h}$. After cooling the mixture to $80{ }^{\circ} \mathrm{C}$, hexane was added and the resulting precipitate was filtered out. The metal complex was extracted with $\mathrm{CH}_{2} \mathrm{Cl}_{2}$ and treated with $\mathrm{KPF}_{6}$ $(0.36 \mathrm{~g}, 2 \mathrm{mmol})$ in $\mathrm{CH}_{2} \mathrm{Cl}_{2}(100 \mathrm{ml})$. The resulting solution was stirred for a week and dried under vacuum. The compound $\mathbf{2}$ was extracted with $\mathrm{CH}_{2} \mathrm{Cl}_{2}$ and recrystallized in $\mathrm{CH}_{2} \mathrm{Cl}_{2}$-ether (yield: $8 \%$ ). MS(FAB) $m / z: 1236\left[\mathrm{CuCuPt}(\mathrm{npa})_{4} \mathrm{Cl}\right]^{+}, 1201\left[\mathrm{CuCuPt}(\mathrm{npa})_{4}\right]^{+}$; EA (\%) $\left[\mathrm{CuCuPt}(\mathrm{npa})_{4} \mathrm{Cl}\right]\left[\mathrm{PF}_{6}\right]$ : calcd. C 48.61, H 2.91, N 12.15; found: C 47.85, H 2.94, N $12.47 \%$.

- Synthesis of 2-naphthyridylphenylamine (Hnpa). Aniline $(10 \mathrm{~mL}$, $110 \mathrm{mmol})$, 2-chloro-1,8-naphthyridine $(5.00 \mathrm{~g}, 30 \mathrm{mmol}), \mathrm{t}-\mathrm{BuOK}$ (5.06 g $45 \mathrm{mmol}), \mathrm{Pd}_{2}(\mathrm{dba})_{3}(0.40 \mathrm{~g} 0.44 \mathrm{mmol})$ and dppp $(0.50 \mathrm{~g}$, $1.2 \mathrm{mmol})(\mathrm{dba}=$ dibenzylideneacetone; $\mathrm{dppp}=1,3$-bis(diphenylphosphino)propane). The mixture was stirred and refluxed for $72 \mathrm{~h}$. The solvent was removed under reduced pressure. The mixture was washed with water and the precipitate was extracted by $\mathrm{CH}_{2} \mathrm{Cl}_{2}$ to obtain a yelloworange product, Hnpa (yield: $73 \%)$. ${ }^{1} \mathrm{H}-\mathrm{NMR}\left(400 \mathrm{MHz},\left(\mathrm{CD}_{3}\right)_{2} \mathrm{SO}\right)$ : $\delta 9.69(\mathrm{~S}, 1 \mathrm{H}), 8.76(\mathrm{~m}, 1 \mathrm{H}), 8.14(\mathrm{dd}, J=8,2 \mathrm{~Hz}, 1 \mathrm{H}), 8.08(\mathrm{~d}, J=$ $8.8 \mathrm{~Hz}, 1 \mathrm{H}), 8.02(\mathrm{dd}, J=8.8,1.2 \mathrm{~Hz}, 2 \mathrm{H}), 7.31(\mathrm{~m}, 3 \mathrm{H}), 6.98(\mathrm{t}, J=$ $7.2 \mathrm{~Hz}, 2 \mathrm{H})$; $\mathrm{MS}(\mathrm{FAB}) m / z 222.1\left([\mathrm{M}+\mathrm{H}]^{+}\right)$.

$\|$ Crystal data for $1: \mathrm{C}_{59} \mathrm{H}_{47} \mathrm{ClCu}_{2} \mathrm{~F}_{6} \mathrm{~N}_{13} \mathrm{OPPd}, M_{\mathrm{w}}=1368.00$, monoclinic, space group $C 2 / c, a=31.1796(17) \AA, b=12.1561(6) \AA$, $c=19.9041(10) \AA, \alpha=90^{\circ}, \beta=129.573(1)^{\circ}, \gamma=90^{\circ}, V=$ $5815.1(5) \AA^{3}, Z=4, d_{\text {(calcd) }}=1.563 \mathrm{Mg} \mathrm{m}^{-3}, T=150(2) \mathrm{K}, 28183$ reflection collected, 6687 independent, $R_{\text {int }}=0.0555, R_{1}=0.0940$, $\mathrm{w} R_{2}=0.2394$ for all data. Crystal data for $2: \mathrm{C}_{60} \mathrm{H}_{48} \mathrm{Cl}_{9} \mathrm{Cu}_{2} \mathrm{~F}_{6} \mathrm{~N}_{12} \mathrm{PPt}$,
$M_{\mathrm{w}}=1723.29$, tetragonal, space group $P 4 / n, a=16.9276(2) \AA, c=$ $11.5475(2) \AA, V=3308.86(8) \AA^{3}, Z=2, d_{\text {(calcd) }}=1.730 \mathrm{Mg} \mathrm{m}^{-3}$, $T=150(2) \mathrm{K}, 19222$ reflection collected, 3776 independent, $R_{\text {int }}=$ $0.0484, R_{1}=0.0861, \mathrm{w} R_{2}=0.2224$ for all data. CCDC 703959 and 703960 .

1 (a) Extended Linear Chain Compounds, ed. J. S. Miller, Plenum, New York, 1982, vol. 1-3; (b) S. Roth, One-Dimensional Metals, VCH, New York, 1995; (c) M. H. Chisholm and N. J. Patmore, Acc. Chem. Res., 2007, 40, 19.

2 (a) J. F. Berry, F. A. Cotton, P. Lei, T. Lu and C. A. Murillo, Inorg. Chem., 2003, 42, 3534; (b) L.-G. Zhu and S.-M. Peng, Wuji Huaxue Xuebao, 2002, 18, 117; (c) C.-Y. Yeh, C.-C. Wang, C.-h. Chen and S.-M. Peng, in Nano Redox Sites: Nano-Space Control and its Applications, ed. T. Hirao, Springer, Berlin, 2006, ch. 5, pp. 85-117; (d) J. K. Bera and K. R. Dunbar, Angew. Chem., Int. Ed., 2002, 41, 4453.

3 (a) S.-Y. Lin, I.-W. P. Chen, C.-h. Chen, M.-H. Hsieh, C.-Y. Yeh, T.-W. Lin, Y.-H. Chen and S.-M. Peng, J. Phys. Chem. B, 2004, 108, 959; (b) I.-W. P. Chen, M.-D. Fu, W.-H. Tseng, J.-H. Yu, S.-H. Wu, C.-J. Ku, C.-h. Chen and S.-M. Peng, Angew. Chem., Int. Ed., 2006, 45, 5814; (c) D. H. Chae, J. F. Berry, F. A. Cotton, C. A. Murillo and Z. Yao, Nano Lett., 2006, 6, 165; (d) I. P.-C. Liu, M. Bénard, H. Hasanov, I.-W. P. Chen, W.-H. Tseng, M.-D. Fu, M.-M. Rohmer, C.-h. Chen, G.-H. Lee and S.-M. Peng, Chem.-Eur. J., 2007, 13, 8667.

4 (a) M.-M. Rohmer, I. P.-C. Liu, J.-C. Lin, M.-J. Chiu, G.-H. Lee, M. Bénard, X. López and S.-M. Peng, Angew. Chem., Int. Ed., 2007, 46, 3533; (b) I. P.-C. Liu, G.-H. Lee, S.-M. Peng, M. Bénard and M.-M. Rohmer, Inorg. Chem., 2007, 46, 9602; (c) G.-C. Huang, M. Bénard, M.-M. Rohmer, L.-A. Li, M.-J. Chiu, C.-Y. Yeh, G.-H. Lee and S.-M. Peng, Eur. J. Inorg. Chem., 2008, 11, 1767; (d) M. Nippe and J. F. Berry, J. Am. Chem. Soc., 2007, 129, 12684.

5 (a) C. Reichardt and W. Scheibelein, Tetrahedron Lett., 1977, 24, 2087; (b) G. R. Newkome, S. J. Garbis, V. K. Majestic, F. R. Fronczek and G. Chiari, J. Org. Chem., 1981, 46, 833.

6 (a) P. A. M. Dirac, Proc. R. Soc. London, Ser. A, 1926, 112, 661; P. A. M. Dirac, Proc. R. Soc. London, Ser. A, 1929, 123, 714; (b) W. Heisenberg, Z. Phys., 1926, 38, 411; (c) J. H. van Vleck, Theory of Electric and Magnetic Susceptibilities, Oxford University Press, London, 1932.

7 (a) F. A. Cotton, P. Lei and C. A. Murillo, Inorg. Chim. Acta, 2003, 351, 183; (b) Y.-H. Shi, W.-Z. Chen, K. D. John, R. E. Da Re, J. L. Cohn, G.-L. Xu, J. L. Eglin, A. P. Sattelberger, C. R. Hare and T. Ren, Inorg. Chem., 2005, 44, 5719.

8 L. Gutiérrez, G. Alzuet, J. Borrás, A. Castiñeiras, A. RodríguezFortea and E. Ruiz, Inorg. Chem., 2001, 40, 3089.

9 M. J. Frisch, et al., GAUSSIAN 03, Revision B.05, Gaussian, Inc., Pittsburgh, PA, 2003.

10 A. Aviram and M. A. Ratner, Chem. Phys. Lett., 1974, 29, 277.

11 See for example and references therein (a) R. M. Metzger, Chem. Rev., 2003, 103, 3803; (b) G. Ho, J. R. Heath, M. Kondratenko, D. F. Perepichka, K. Arseneault, M. Pézolet and M. R. Bryce, Chem.-Eur. J., 2005, 11, 2914; (c) J.-W. Ying, A. Cordova, T. Y. Ren, G.-L. Xu and T. Ren, Chem.-Eur. J., 2007, 13, 6874; (d) M. K. Ng, D. C. Lee and L. P. Yu, J. Am. Chem. Soc., 2002, 124, 11862; (e) P. Jiang, G. M. Morales, W. You and L. P. Yu, Angew. Chem., Int. Ed., 2004, 43, 4471. 